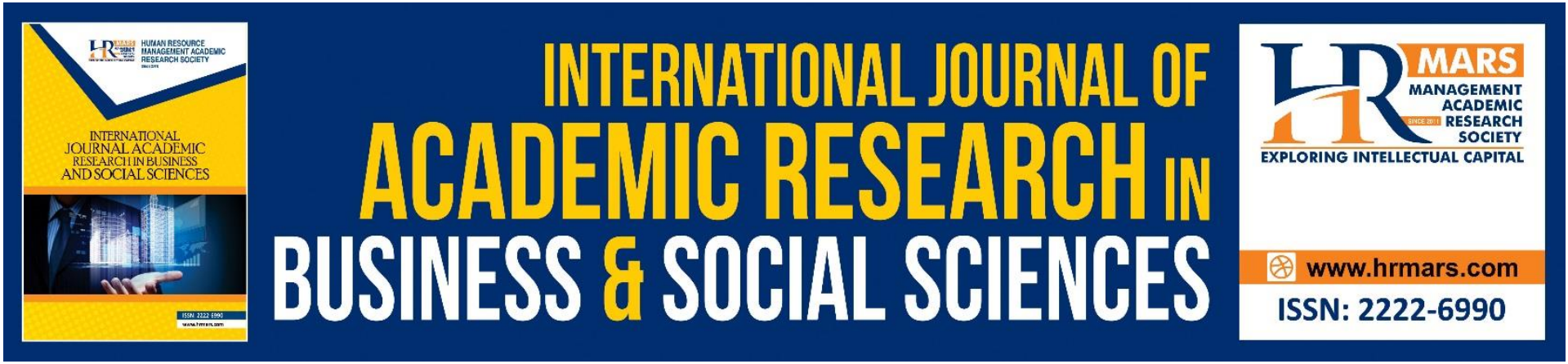

\title{
Empowering Informal Caregivers and Care for Family
}

\section{Nur Saadah Mohamad Aun \& Noremy Md. Akhir}

To Link this Article: http://dx.doi.org/10.6007/IJARBSS/v11-i3/8958 DOI:10.6007/IJARBSS/v11-i3/8958

Received: 02 February 2021, Revised: 28 February 2021, Accepted: 09 March 2021

Published Online: 17 March 2021

In-Text Citation: (Aun \& Akhir, 2021)

To Cite this Article: Aun, N. S. M., \& Akhir, N. M. (2021). Empowering Informal Caregivers and Care for Family. International Journal of Academic Research in Business and Social Sciences, 11(3), 444-452.

Copyright: (c) 2021 The Author(s)

Published by Human Resource Management Academic Research Society (www.hrmars.com)

This article is published under the Creative Commons Attribution (CC BY 4.0) license. Anyone may reproduce, distribute, translate and create derivative works of this article (for both commercial and non-commercial purposes), subject to full attribution to the original publication and authors. The full terms of this license may be seen at: http://creativecommons.org/licences/by/4.0/legalcode

Vol. 11, No. 3, 2021, Pg. 444 - 452

Full Terms \& Conditions of access and use can be found at http://hrmars.com/index.php/pages/detail/publication-ethics 


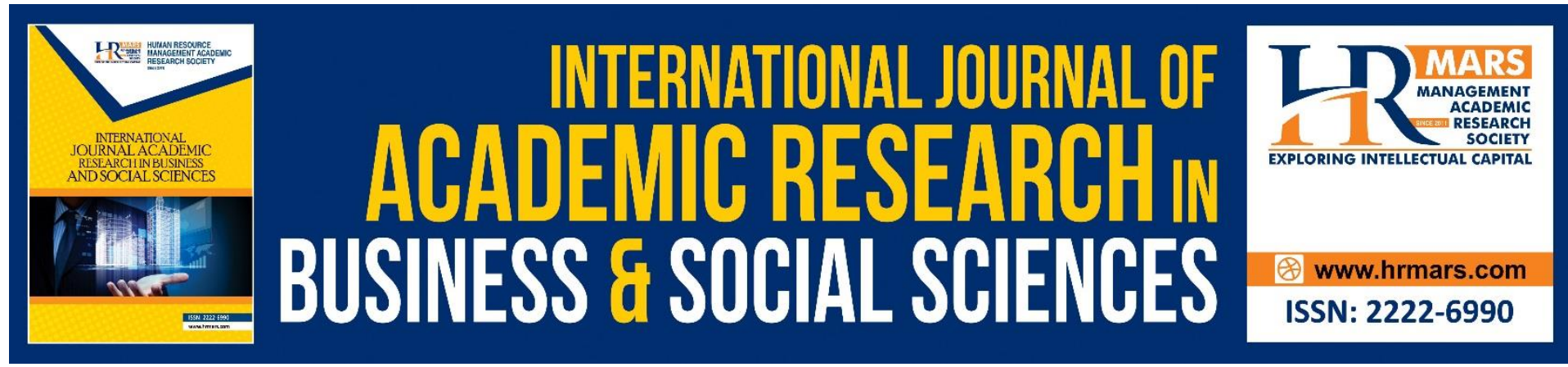

\title{
Empowering Informal Caregivers and Care for Family
}

\author{
Nur Saadah Mohamad Aun \& Noremy Md. Akhir \\ Centre for Research in Psychology and Human Well-Being, Faculty of Social Sciences and \\ Humanities, Universiti Kebangsaan Malaysia \\ Email: noremy@ukm.edu.my
}

\begin{abstract}
Malaysia is one of the fastest growing countries in Southeast Asia. This development process has resulted in the migration of population from the countryside to the city because of job opportunities that are offered. It is associated with rising standards of living, longer life expectancy and the increasing participation of women in the employment sector. However, the changes also impose costs directly and indirectly to the family. This is because the number of individuals who offer services as informal caregivers is decreasing. As more women involved in the labour force, they would not have much time to care for children, elderly parents, the sick and disabled of their family members. In fact, the imbalance role in the family and workplace may cause some women for not having more children, or decided not to married. It was certainly an impact on the country's population in the future. Consequently, a mechanism to address the issue of providing informal care should be taken seriously. Informal caregivers do not need to focus on women and the family alone. As the people who need care are men and women, then it is the time for men strive to be the caregivers. Moreover, the burden of care should not be left to the family alone but share with other social institutions. Therefore, this paper discusses the issues related to the empowerment of informal caregivers and care for the family.
\end{abstract}

Keywords: Empowering, Family, Informal Caregiving, Malaysia

\section{Introduction}

The process of rapid development in Malaysia over the past half century has resulted transformation in many aspects of life. Economic transformation from an agricultural to an industrial-focused and trade not only resulted in the growth of large cities and industrial areas but also a migration of population from rural to urban. Estimated rate of rural to urban migration and city to city in 2008 was 64.9 per cent, compared to rural migration to the countryside and the city to the countryside by 35.1 per cent. According to Milah, Siti Raba'ah and Rosmiza (2020), Malaysia population is increase to 32.4 million in 2020 from 31.7 million in 2018, while urban population is increase to 25.0 million in 2020 from 24.1 million in 2018. Furthermore, the urbanization rate in Malaysia is 77\% in 2020 and it is estimated to increase $85 \%$ by 2040 and will keep increase by 2050 (PLANMalaysia, 2016). Associated with this rapid development in both physical and economic aspects, it is also a raising of living standards, 
longer life expectancy and the increasing participation of women in the labour force. Furthermore, women need to work to earn a living for their family especially those living in cities (Marziah et al., 2020). Even though the estimated life expectancy of Malaysians is remained at 74.5 years in 2019, and as recorded in 2013 (Department of Statistics Malaysia, 2019), the overall percentage of women working is still high. The National Population and Family Development Board (2014) stated that, $46.5 \%$ of women are currently working, $42.4 \%$ have worked before, and $11.1 \%$ have never worked. It was also found that almost one-fifth $(18.7 \%)$ of the women who are currently working, are facing problems in balancing their roles between their work and the family. Among the main problems faced are less time spent with the family $(51.9 \%)$, childcare problems (13.0\%), less time for own self $(11.9 \%)$ and workload at the workplace (11.2\%). This will impose an amount of costs directly and indirectly to the community, especially the family. These costs can be seen in terms of family's ability to perform the functions of care, which is one of the important functions that must be implemented by the family to ensure its continuity. Therefore, it is importance of achieving happiness in a family as every family member comes with the responsibility to taking care of other persons. Those persons include children and other family members (Suzana \& Siti Marziah, 2019). However, most families today, especially those living in the city is the inability to fully implement each of the main functions. Function of the family in educating children has shared with schools and non-formal educational institutions to another. Besides, functions of sick family members are also have been taken over by the hospital.

Raising up children and caring for the sick and disabled are not only done in the home and family environment but has handed over to those with no family connections for instance maids. Some even hand over to formal institutions or other organizations. As more women involved in the labour force, they would not have much time to care for children, elderly parents and family members who are sick and disabled. In fact, if they themselves are faced with problems such as chronic illness, the role have to be handed over to other people who do not have family ties. This is because the spouse (husband or wife) cannot continue to be a caregiver because of the conflict role between role in a family and a role in employment. It is supported by Siti Marziah et al. (2020), where workload was a major source of work-family imbalance followed by role-conflict. Therefore, the easiest solution is to find the maid. The question is to what extent the family can leave or hand over it to any other individuals or organizations? This is because, in some circumstances, some people cannot offer service or give fully responsibilities compare to what is usually provide by family members, particularly mothers or wives. This is because the paid service is not doing care tasks with passion and love as given by family member. Whereas, the feeling of love and affection, a string of reciprocal relationships or sense of responsibility among family members are significant features as informal caregivers (Twigg \& Atkin, 1994; Evandrou \& Winter, 1992). In addition, domestic issues become more complex over time. The difficulties associated with the problems raised by both parties (maid and employer) which the maids being abuse and neglect by the employer. In addition, an issue that complicates the recruitment of maids to work with the family in this country are matters related to the recruitment procedure, minimum wage, job tasks and also leave. Therefore, it is not a surprise that many women in middle age stop working because she wanted to give full attention to the family (Fatimang, 2009).

The role in a family and workplace are not only need to be balanced but the issue that led to some women who do not want more children, or do not want kids and decided not to get married should be taken seriously. This is because, it would also impact on the country's 
population in the future, particularly in terms of accretion population, the lack of young people and the burden of care for the elderly. Based on the above issue, this paper discusses on care for the family particularly with regard to informal care. Besides trying to produce a mechanism to address the issue of providing informal care, this paper also highlights the important issues related to the care of the family that should be given attention. Some of the caregivers reported experiencing distress and burden which correlated with their lower quality of life (Norhayati et al., 2016). Authors are trying to stress a relation of informal care; not only focus on women, but to bring a new perspective to the man execution of the role. As the people who need care are men and women, then it is time for men to also strive to be the caregivers. Moreover, the burden of care should not be hand over to the family alone but share with other social institutions as well. The first part of the discussion is about the cycle of family care assistance which needed. The second part is about care scenario in the past and the present situation, and the third part will touch on issues related to the empowerment of caregivers and informal caregiving in family. The data presented in this paper is based on several studies of informal care (Fatimah et al., 2013; Siti Hajar et al., 2014; Nur Saadah, 2012).

Informal caregivers are referred to individuals who take the initiative to care for family members who are unable to care for themselves in some or all aspects of the physical and emotional activities such as bathing, personal care, financial management and other activities (Viitanen, 2007). Those who receive care also require special care because of mental illness or chronic pain. Informal care is about all forms of care provided by informal caregivers of chronically ill or disabled. Care is done because of family relationships, love and sympathy to patients (Fatimah, 2009). As noted earlier, empowering informal care within the family is very important if a country want to get greater participation among working women in order to reduce stress in the family thus increasing the well-being of the family. Empowerment is also play an important role if the society would like to see less social problems stemming from the family.

\section{Methodology}

This paper is a conceptual review based on review of past studies on caregiving. This review was carried out using secondary data collected from related multiple sources on the topic of caregiving and family such as journals, conference proceedings, books, reports from governmental and non-governmental organizations, newspapers, and website resources from year 1992 until 2020.

\section{Discussion}

\section{Family Needs to Informal Care: Present Family Scenario}

Almost all family are going through one phase to another phases in life. This development is referring as family life cycle. The family life cycle has its advantages and disadvantages. This is because there are tasks to be fulfilled by each family member at every phase of family life cycle. Starting from the young unattached adult, the newly married couple, the family with young children, the family of midlife: adolescents and aging parents, the stage of launching children and moving on, and the family in later life. They claimed that human's experiences in passing through the family life cycle are affected by social changes for instance the death of family member. The newly married couple tends to have a high level of family strengths, including self-disclosure, loyalty, trust, and respect. The couple with young children faces the challenge of taking on the roles of mother and father as well as husband and wife and of enlarging the family system to include other people. 
The family at midlife faces multiple challenges: the care of aging parents who become ill or disabled and illness or death of one of the spouses. Those who care for aging parents as well as adolescent children constitute the "sandwich generation." The great majority of the elderly are cared for by their children for all or most of their later years. But caregiving is stressful. Many caregivers need to call on community resources to help (Nur Saadah, Siti Hajar $\&$ Rezaul, 2014). The quality of care in nursing homes varies considerably, indicating the need for thorough investigation before institutionalizing a parent. The aging family involves a shift of roles, with the middle generation taking on a more central place in the family. Retirement occurs at this stage. People may adjust well to, or even welcome, retirement when it is voluntary.

Meanwhile, working parents (either one or both of them work) get retire, they are staying alone after all the children married and left themselves. Although there are families or individuals who do not go through these phases because they are not married or do not have children, most of the families are basically performing their lifetime care because they know family members need to be cared. Let us put into consideration each of the above mentioned one by one and understands the needs of families in getting support from other parties, both members of the nuclear family and extended family or community members (Fatimah et al. 2013). Social supports are instrumental support (both in-kinds and in-cash), energy, time consuming or any other form of direct assistance (such as bring to the hospital for treatment, prepare and keep food and drink). In summary, care needs can be divided into; care in family development, care for families in pre-school children, care after the kids go to school, care for families in the middle-aged, and care for families in final stage.

\section{Care in Family Development: Entry Level}

In family, women always play a main role as a caregiver. It started from taking care of baby after delivery until aging age. Traditionally, the role of post-natal care for women and their babies are exclusive to the mother. However, in the context of tradition, many women who have just become parents usually will be assisted by their own mother or mother-in-law and other adult women who are members of the extended family. Intensive care for at least forty days is very important and is emphasized in the Malay society. At that time, women who have just given birth have been told to abstain in various aspects such as food, not doing house work and other heavy work, taking certain medications and herbal medicine to restore health, and many more. In traditional Malay society, mother or mother-in-law and sometimes assisted by traditional midwives or women, commonly would share in maternity care work. There are many things related to health care and rehabilitation as bertungku (using hot stone), drinking herbal medicine, and massage. At the same time, mother, mother-in-law or other women were together taking care of a new born baby as well as help to manage the household like cooking, house cleaning and washing clothes for other family members. Mother or mother-in-law always did the job for free while other women will be paid according to their tasks. Now, support care by the mother or mother-in-law is no longer available especially for those who live in the city. This is because most of them (mother or mother-inlaw) refuse to come to the city and stay in a period of time or over a week especially if they still have a husband and other children or also having to maintain livestock and crops in the village.

Consequently, many women who delivered had decided to continue treatment if there was relatively expensive. Furthermore, the maid is assign to do some work to care for her and also doing house works. However, recently the management of foreign workers has 
announced that one maid is limited to do one task only. Then, this is a problem to many families when the wife is need for post-natal care and at the same time have other children to take care of. For this reason, there might be women who returned to his hometown for a few weeks to get post-natal care from their mother or mother-in-law and the midwife in the village. But it's just easy to do if they do not have another child or other children not yet in school. On the other hand, if they already have schooling children, the option to return to their village would not be appropriate.

\section{Care for Schooling Children}

Care needs for children to enter school. This is because the time they are in school (either morning or afternoon) is not same as parents at work. Problems may arise if not many houses near the school where they could take care of themselves and go home by themselves. Furthermore, young children should be directly managed by their parents. However, with the case of missing children, rape and murder, kidnapping and others criminals have threatened children and parents to deal with it by themselves. The cases mentioned were often reported in the local press.

Provide care for children already in school, are quite complicated especially if the parents or one of them work in different places, outstation or work abroad. The same problem arises when school holidays and working parents cannot take time off. Many families leave their children alone at home or being a caregiver for younger siblings when their parents go out for work. This concept was formerly known as the "latch-key kids". This is also exposing to a danger especially in the event of an accident at home, robbery and so on (Fatimah, Khaidzir \& Omar, 2003).

\section{Care for the Family: Middle Age}

At this point, many families face with the problem of providing care for members of their own family and taking care of elderly parents. At this stage also, parents should take care of growing children and at the same time disabled parents and parents-in-law due to medical reasons. Most parents or parents-in-law often live in remote home of their children who mostly live in the city. The situation becomes more complicated because at the same time working spouses have responsibility as well on their jobs. Married couples who are in the middle age are usually referred to as the sandwich generation as they huddled between the tasks of managing their own family and take care of the elderly parents. Based on the studies that have been done, most of the family members had to organize disabled family members and at the same time does not affect their work. Among them is to hire a maid or sent to institutions (Fatimah, 2006) and stopped working (Nur Saadah, 2012; Fatimang, Rahmah \& Fatimah, 2009).

\section{Care for the Family: Final Stage}

At each level of the above mentioned case, a lot of families require special care for their family members whom are mentally ill, physically handicapped and chronically ill. Family care and providing care for a family member is always seen as a private affair. With such a view, it is not surprise that many families do not provide full care for family members (Nur Saadah, 2012).

If the family is always regarded as the most important institution in society, so any other family problems that plague in should be given serious attention. In the context of this paper, the problems faced by many families today is how to ensure that they would continue 
to remain calm in facing many challenges without neglecting social functions. One of those social functions is to provide care for family members who are ill, disabled, elderly and special needs (Siti Hajar et. al, 2014). Nevertheless, most of informal caregiver (family), seen able to work, yet their family member need continuous attention. On average they are not able to send their family members on day care services as most of the care service centres which involve cost and they are unable to afford it (Nur Saadah \& Rusyda, 2016). The problem happens when the social function is not allocated in a balance manner among the family members. In other words, most of the adult women, especially wife/mother, bear full responsibility in providing care, even though they are carrier women. If parents cannot afford for some reason, it is not easy to other family members; especially men, to take over the role played by the wife/mother. Empowerment can be done in both inside and outside the family. Among them are:

1. In the family: the process of socialization of the children in the family is no longer done or separated by gender.

2. Outside the family: the other social institutions must be sensitive to the needs of the family.

3. Provision of physical facilities for family members who need special care is necessary. Care issue is the issue of life. As stated earlier, it is started since the establishment of the family institution until retirement and their children leave the family orientation (especially their parents). The orientation again begins when the married children are forming their own families as well. Common assumption is that most of the family members who need care are children, women (due to childbirth) and the elderly, then the role of a caregiver is often attached to women. It also has to do with the traditional socialization process that is based on gender differences. Thus women are seen more suitable to be the caregiver and perform the role of care than men. However, in the current life, family members with disabilities are not necessarily women. Men are also faced with the same situation especially disability due to an accident at work, road accidents, chronic disease and many more. In this regard, the empowerment of male family members also is a need to enable them to take over the role as caregiver played by women.

Male caregiver also needs to be given particular attention in the context of MalayMuslim families. If the patient or disabled person is male, others than his mother, wife, daughter, granddaughter and sister or aunt, other women such as female cousins and maids (women) would not fit to be a caregiver. Even his daughter in law, it would be inappropriate to take care of her illness or disabled father-in-law, especially involving physical care. Therefore, as stated in an earlier part, young men graduate from school and college or university should be given the skills to be informal caregivers. They can make this task as caregiver of formal job or a side job that can give them income, based on allowance prescribed by the authorities. Indirectly, this will reduce dependency on foreign maids or caregivers.

\section{Summary}

This paper has touched generally on informal care, and more focused on the urban area and mostly have working spouses. These families were living far from extended family relatives. Furthermore, their spouses or other family members are also working and this make their role as caregivers limited. For high-income families from middle and upper class, this does not pose much of a problem because they can use the services offered anytime. However, many of them are from lower class families with low income and have to do extra works to increase 
their family economy such as doing business. Their extra works time is mostly dealing with the conflict between role of caring for family members with disabilities and at the same time trying to earn family income.

Informal care services available in our community are not reachable to all socioeconomic class. Care in institutions especially private institutions would not be affordable for most families. Meanwhile, the institutions provided by the authorities are still limited in number and quality of care was often questioned due to reports of neglecting, lack of staff and lack of monitoring. As a result of changes in family demography, the needs of informal caregivers and care will continue to be an important issue to many families nowadays and in the future. Accordingly, this paper assumes that it is a time to have a data bank that can provide information about the need for informal caregivers and care for the family. That information can be used as the basis for policy planning related to the needs of volunteers (such as giving allowances by the government), whom can provide services to the family at any time needed. As related to the family, young school leavers or college and university students, housewives and single mothers should be encouraged to register as a volunteer in the informal caregivers. A particular organization may be the coordinator for the relationship between the two parties; those who offering services and those who consume the services.

\section{References}

Department of Statistic Malaysia. (2019). Abridged Life Tables 2013-2019. Putrajaya. Department of Statistics Malaysia.

Evandrou, M., \& Winter, D. (1992). Informal carers and the labour market in Britain. United Kingdom: Economic \& Social Research Council.

Fatimah, A.(2009). Informal caregivers and care: Issues and challenges. The Malaysian Journal of Social Administration, 9, 73-86.

Fatimah, A. (2006). The function of family in care: Issues and challenges. Seminar of Psychology Community Development ISM-UKM: Psychosocial approach in empowering community development organized by the Centre for Psychology and Human Development, UKM \& Institut Sosial Malaysia, at Kuala Lumpur on 21-22 December 2006.

Fatimah, A., \& Khaidzir, I., \& Mustaffa, O. (2003). "Latch-key Kids: Issues and Challenges", Proceeding National Seminar on Family. Centre for Psychology and Human Development, 181-189.

Fatimang, L., Rahmah, M. A., \& Fatimah, A. (2009). Penjaga wanita bagi warga tua pesakit strok di bandar. The Malaysian Journal of Social Administration, 6, 57-71.

National Population and Family Development Board. (2014). Report on Key Findings of Fifth Malaysian Population And Family Survey (MPFS-5) 2014. Kuala Lumpur. National Population and Family Development Board.

Milah, Z., Siti Raba'ah, H., \& Rosmiza, M. Z. (2020). The role of social assets of community well-being in urban farming project. Journal of Asian Scientific Research. 10 (4), 255263.

Norhayati, I., Hui C. O., Suzaily, A. W., Normah, C. D., Mahadir, A., Noh, A., \& Suhaimi, M. (2016). Psychological well-being among caregivers of schizophrenia patients in Malaysia. International Journal of Psychology, 678-679.

Nur Saadah, M. A. \& Rusyda Helma, M. (2016). Informal caregiving: Empowering social support programs by employers. Akademika, 86(1), 3-9. 
Nur Saadah M. A., Siti Hajar, A. B., \& Rezaul, I. (2014). Coping Strategies Among Mothers Of Chronically III Children: A Case Study In Malaysia. Journal Of Social Service Research. 40, 160-177.

Nur Saadah, M. A. (2012). Coping Strategy Among Informal Caregivers of Chronic Illness Patients In Malaysia, Proceeding The Eight International Malaysian Studies Conference, at Universiti Kebangsaan Malaysia Bangi, Selangor on 9-11 July.

PLANMalaysia. (2016). Basic Malasyian data. $3^{\text {rd }}$ National Physical Plan. Kuala Lumpur: Department of Town and country planning.

Siti Hajar, A. B., Richard, W., Noralina, O., Fatimah, A., \& Nur Saadah, M. A. (2014). Projecting social support needs of informal caregivers in Malaysia, Health and Social Care 22(2), 144-154.

Siti Marziah, Z., Noremy, M. A., Izzat, M. E., Hawa, R., \& Suzana, M. H. (2020). Dual-role women in Selangor: Work-family conflict and its impact on emotional well-being. International Journal of Psychosocial Rehabilitation, 24(4), 4103-4114.

Suzana, M. H., \& Siti Marziah, Z. (2019). Marital satisfaction and general happiness among urban Malays in Klang Valley. International Journal of Recent Technology and Engineering, 8 (2S10), 97-110.

Twigg, J., \& Atkin, K. (1994). Carers perceived: policy and practice in informal care. Buckingham: Open University Press.

Viitanen, T. K. (2007). Informal and formal care in Europe. Discussion Paper Series, 2648 (February), 1-24. 